\title{
Climate Change Effects and Quality Makhana (Euryale ferox Salisb.) Production under Wetland Ecosystem of North Bihar
}

\author{
B.R. Jana, Anuradha Srivastava* and Md. Idris
}

ICAR-RCER, Research Centre for Makhana, Basudeopur, Darbhanga, Bihar-846005

*ICAR-RCER, Research Centre Ranchi, Namkum, Ranchi, Jharkhand-834010

*Corresponding author

Key w o r d s
Makhana, Different
$\begin{aligned} & \text { Seasons, Gestation } \\ & \text { Periods, Fruits, } \\ & \text { Protein content and } \\ & \text { yield }\end{aligned}$
Article Info
Accepted:
07 November 2018
Available Online:
10 December 2018

\section{Introduction}

The plant makhana or fox nut (Euryale ferox Salisb.) belongs to the family Nymphaeaceae, have commercial importance due to its seeds which contain unique amino acid composition. It is an aquatic plant grows in stagnant water of lakes and lowland and widely found in
A field trial was conducted to study the climate change effects on quality makhana production at ICAR-RCER, Research Centre on Makhana during 2016-2017. The objectives of the study were developing new makhana production strategies to secure sustainable production under climate change or various weather conditions. High temperature and reduced humidity resulted in production of rather smaller nuts and leaves. The results revealed that makhana was a photo insensitive crop and its growth and development were markedly changed with the change of climates. Fruit number, seed numbers/fruits and yield were gradually increased from February to till September. Winter climate restricted commercial production of makhana for October transplanted crop. However, November and December planted makhana produced yield similar to January crop after recovering from unfavourable weather of winter. The maximum numbers of fruit (15.33) and yield (62.0Q/ha) were observed in September planted crop. The gestation period of this crop was minimum (110 days) in February planted crop as compared to October (152 days). Winter makhana, which was planted in July showed highest nut quality in terms of protein $(11.35 \%)$ content. Plant grown in extreme winter and summer showed decreased in protein content. As far as pest infestation was concerned, the aphid (Rhopalosiphum nymphaeae) was found infesting makhana crop at nursery stage in winter. However, no economic damage was observed. During this study, the maximum temperature was $43^{0} \mathrm{C}$ in May (2016) and the minimum temperature was $5^{\circ} \mathrm{C}$ in January (2017). Hence, high and low temperature resulted in reduction in growth parameters (nut and leaf), while moderate temperature enhances protein production and yield. 
this species is now limited to the tropical and subtropical regions of south-east and East Asia. It has been adapted to the tropical climate of India and is found in natural, wild forms in various parts of north-east India (Manipur Assam, Meghalya, and Orissa) and scattered pockets of central and northern India (e.g. Vadodhara. Gorakhpur and Alwar) (Kak, 1985; Shankar et al., 2010). Fox nut plant is stem less having large round leaves and produces bright purple flowers. Being a thorny plant, it needs less water its growth but more for floating of the leaves and flowers (Jana, 2017). In Bihar, particularly in Mithila region is well known for Makhana cultivation under wetland ecosystem since several years ago. Swamp and marshy areas having stagnant water (Kumar et al., 2011) is ideal for cultivation and it has become the pride of poor farmer to provide complete food and nutritional security to the people of this region. With the burgeoning population and urbanization cultivable ponds and field are decreasing day by day. It is also good for sugar patient and developing child as it contains the maximum calcium and other nutrients. The seeds of fox nut are used in ayurvedic preparations (Jha et al., 1991a). It strengthens the heart and is very useful in anaemia (Das et al., 2006). It is also an important ingredient which is used to strengthen spleen and kidneys. It contains less sodium and maximum potassium which reduces blood pressure. It is effective against neuralgia, incontinence, chronic diarrhoea and arthritis (Jha et al., 1991b). It is nutritious and easily digested (Singh and Arora 1978). Its medicinal properties lying on treating circulatory disorders and also as a cardiac stimulant is praise worthy. In pond system of cultivation, the production was very low (1.0$1.2 \mathrm{t} / \mathrm{ha})$. In Bihar, makhana has been cultivated on 11,802 ha that accounted for total yield of 3,37,59.1 T (JIT Report, 2014). Since 1990 Besides being an wonderful aquatic non cereal food crop the area of cultivation is dwindling (In 1990 area was 90,000 ha) due to high temperature, reduced relative humidity and limited water resources which are the major factors resulted in reduction in yield. As the area of water resources are shrinking sustainable management of biotic resources in the wet lands of North Bihar has great important for livelihood security to the rural poor (Jha, 2002). Hatfield et al., (2011), stated that pollination is one of the most sensitive phonological stages to temperature extremes and greatly affect crop production in all crop species and during plant growth stages. The expected changes in temperature over the next $30-50$ years are predicted to be in the range of 2-3 ${ }^{\circ} \mathrm{C}$, Intergovernmental Panel Climate Change (IPCC) (2007). Both cooler and warm temperature affects the protein synthesis and yield. Below $20^{\circ} \mathrm{C}$, loss of membrane fluidity might explain the inactivation of membranebound processes such as photosynthesis and ion transport and thereby protein synthesis (Graham and Patterson (1982). While studying on protein synthesis in Pear, Ferguson et al., (1994) stated that heat-shock protein (hsp) synthesis was greater at $39^{\circ} \mathrm{C}$ than at temperatures above $40^{\circ} \mathrm{C}$. Both cellular uptake of radiolabeled methionine and total protein synthesis were progressively lower as the temperature was increased $\left(45^{\circ} \mathrm{C}\right)$.

To augment the production and maintenance of nut quality under climate change scenario is itself a big challenge to the researchers. Hence, in present study, makhana were grown in twelve different months to assess the actual requirement of crop for maximum production as well as growth of crop and nut quality affected by seasons. The 10 years growth data are also collated to find out the differences in growth parameters.

\section{Materials and Methods}

The present study was conducted at ICARRCER, Research Centre for Makhana during 
2016-17. It is located in the Adhwara-Kamla flood plain (lat $26010^{\prime} \mathrm{N}$ : long, 850 87'). Makhana thrives best in weather having air temperature $20-25^{\circ} \mathrm{C}$ relative humidity $50-90$ $\%$ and annual rainfall 100-250 cm (Mandal et al., 2010). So assured irrigation or water for maintenance of makhana plant growth and maturity is essential. Cultivar for experiment was Swarna Baidehi, first ever variety released from the Research Centre of Makhana. Planting date was first week of every month and $30 \mathrm{~cm}$ constant water was provided under field condition for proper growth and development. Growth data were taken by standard methods. Data were analyzed by following RBD with 3 replications. Protein was measured by Lowry method and carbohydrates were determined by the Anthrone method (Ranganna, 1997, Thimmaiah, 1999). Dried samples (1g) were digested with diacid mixture (HNO3: HClO4: 9:4). After digestion and extraction of samples, total $\mathrm{P}$ was determined with the vanodo-molybdophosphoric acid yellowcolour method (Jackson, 1973) and total K was determined with the flame photometric method (Jackson, 1973). Water-soluble Ca and $\mathrm{Mg}$ were determined by the versanate method (Hesse, 1971). Water-soluble Fe was measured with an atomic absorption spectrophotometer (Analyst 100, Perkin Elmer, and Norwalk, CT, USA).

\section{Results and Discussion}

\section{Morphological and bio-chemical effect}

A close perusal of the table 1 revealed that due to climate change in respect of raising temperature, decreasing relative humidity and rainfall over the decades (2007-2016) nut size of makhana were relatively smaller as well as kernel \% was reduced (63.15\%-61.74 \%). Similarly, the leaf size was significantly decreased (110.48 -106.57) due to high temperature and reduced humidity from decade of study. Data of the table 3 enable us to explain not only leaf sizes but also leaf number was also affected by the high temperature. Apart from nut and leaves the number of floral buds were also decreases from (16.34- 14.62). Makhana is generally grown all over India during June-September in ponds and lowland traditionally. From study of CSIR (1952) to present study (2016) the protein \% was increased from 9.7 to $11.16 \%$. But in the both extreme temperature high and low protein synthesis declines in seasonal study 2016-17 (Fig. 2). Moderately Low temperature, the protein synthesis was the maximum which was reflected in July crop harvested in November (11.35\%). This finding was corroborated by the finding of CSIR (1952) and Shankar et al., (2010) (Table 2). The similar finding was observed by Graham and Patterson (1982) and Ferguson et al., (1994.) Both high temperatures in summer due to severe weed infestation in March -April leaves were in congested space which affects subsequent growth along with high temperature of the water and environment. Summer atmosphere also restricted inform of reduction in floral bud number, leave sizes and petiole length of flower and leaves. The yield of the makhana crop was gradually increased from February to September (16.32 Q/ha to 62.0 Q/ha). It has been found that October planted makhana plant survived during winter but its growth and development was too poor to yield the minimum $(7.67 \mathrm{Q} / \mathrm{ha}$ ) by limiting fruit set per cent (28.24\%). As the August and September planted makhana gave almost double production protein content of the nut decreases little bit (10.92\%) (Fig. 1-3).

\section{Yield}

Data pertaining to table 3 in respect to yield character, the maximum yield of $62.0 \mathrm{Q} / \mathrm{ha}$ was observed in case of September, planted Makhana. By utilizing the retrieved flood water or late monsoon September plantation 
is feasible to harness the maximum production benefit during winter under North Bihar Condition. August transplanted makhana is the second best performer with regard to yield $(40.27 \mathrm{Q} / \mathrm{ha})$, which may practically be fitted to the farmer of North Bihar without taking risk for nursery raising during normal monsoon (3rd week of June) season. Kumar et al., (2011) reported that yield potential of some superior line at field condition was 2.6-3.0T/ha. The biomass production of the crops were the highest in September planted crop both in terms of fresh weight $(33.47 \mathrm{~kg} / \mathrm{plant})$ and dry weight $(4.53$ $\mathrm{kg} / \mathrm{plant}$ ) which incorporate more nutrient to the soil after decomposition. The results were in accordance with the findings of Kumari et al., (2011).

\section{Pollination, fruit set and crop period}

Makhana is predominantly self pollinated crop yet its pollination and fruit set was affected by high temperature and low humidity in different growing seasons i.e. September planted makhana had the maximum fruit set $(86.22 \%)$. This result was confirmed by Hatfield et al., (2011). Fruit contains 180-210 ovules which later developed in to nuts. The maximum seed per fruit was observed 163.25 (Table 4) and its pollination period was mid October for September planted makhana. The gestation period varies from 110 days in February to 152 days in October transplanted crop. Kumar et al., (2011) also reported that makhana is 4.0 months crop (120 days).

Table.1 Climate change and its impact on leaves and nuts over decades (2007-2016)

\begin{tabular}{|c|c|c|c|c|}
\hline Years & Leave Diameter(cm) & Nut weight $(\mathbf{g})$ & Floral Bud & Kernel (\%) \\
\hline $\mathbf{2 0 0 7}$ & 110.48 & 1.22 & 16.34 & 63.15 \\
\hline $\mathbf{2 0 1 6}$ & 106.57 & 1.13 & 14.62 & 61.74 \\
\hline Fisher LSD & 2.64 & NS & 1.15 & 1.21 \\
\hline $\mathbf{P} \mathbf{0 . 5}$ & & & & \\
\hline
\end{tabular}

Table.2 Biochemical changes of kernel powder of makhana 2016

\begin{tabular}{|l|c|c|c|}
\hline Constituents & $\mathbf{1 9 5 2} * *$ & $\mathbf{2 0 0 9} *$ & $\mathbf{2 0 1 6}$ \\
\hline Moisture \% & 12.8 & 10.71 & 11.82 \\
\hline Carbohydrate\% & 76.9 & 70.77 & 75.04 \\
\hline \% Protein & 9.7 & 11.02 & 11.16 \\
\hline Fat\% & N/A* & 0.41 & 0.51 \\
\hline Phosphorus \% & N/A* & 0.08 & 0.028 \\
\hline Sulpher \% & N/A* & 0.024 & 0.042 \\
\hline Calcium \% & N/A* & 0.037 & 0.027 \\
\hline Magnesium \% & N/A* & 0.01 & 0.006 \\
\hline Potassium \% & N/A* & 0.042 & 0.037 \\
\hline Iron \% & 1.4 & 0.004 & 0.006 \\
\hline Ash\% $\%$ & 0.4 & 0.418 & 0.62 \\
\hline Total & $\ldots . .$. & $\mathbf{9 3 . 5 2 5}$ & $\mathbf{9 9 . 2 9 6}$ \\
\hline
\end{tabular}

*Shankar (2010) and Kumar et al., (2011).

** CSIR (1952) 
Table.3 Morphological characters of makhana as affected by different growing seasons (2016-2017)

\begin{tabular}{|c|c|c|c|c|c|c|c|c|}
\hline Treatments & $\begin{array}{c}\text { Leaf } \\
\text { diameter } \\
(\mathbf{c m})\end{array}$ & $\begin{array}{c}\text { Leaf } \\
\text { number }\end{array}$ & $\begin{array}{c}\text { Petiole } \\
\text { Length } \\
(\mathbf{m})\end{array}$ & $\begin{array}{c}\text { Fruit } \\
\text { petiole } \\
\text { length }(\mathbf{c m})\end{array}$ & $\begin{array}{c}\text { Fruit } \\
\text { weight(g) }\end{array}$ & $\begin{array}{c}\text { Number of } \\
\text { fruits/plant }\end{array}$ & $\begin{array}{c}\text { Number } \\
\text { of } \\
\text { seeds/fruit }\end{array}$ \\
\hline FEB & 110.33 & 8.44 & 1.18 & 38.77 & 200.23 & 7.23 & 78.34 & 16.32 \\
\hline MARCH & 116.66 & 8.55 & 1.26 & 40.66 & 205.67 & 8.12 & 82.66 & 18.36 \\
\hline APRJL & 119.17 & 8.75 & 1.29 & 41.66 & 209.08 & 8.22 & 82.99 & 19.25 \\
\hline MAY & 122.34 & 9.92 & 1.32 & 43.26 & 211.33 & 8.88 & 88.52 & 20.92 \\
\hline JUNE & 125.83 & 10.44 & 1.37 & 44.88 & 216.88 & 9.72 & 118.76 & 25.66 \\
\hline JULY & 125.33 & 12.55 & 1.45 & 45.25 & 240.66 & 10.22 & 123.35 & 38.25 \\
\hline AUG & 132.66 & 14.66 & 1.58 & 45.66 & 275.78 & 12.45 & 152.64 & 40.27 \\
\hline SEPT & 137.82 & 15.03 & 1.62 & 47.99 & 324.33 & 15.33 & 163.25 & 62.00 \\
\hline OCT & 101.66 & 12.04 & 1.34 & 28.61 & 155.73 & 6.92 & 34.67 & 7.67 \\
\hline NOV & 104.17 & 10.25 & 1.36 & 26.29 & 187.38 & 6.62 & 72.88 & 10.33 \\
\hline DEC & 105.33 & 10.67 & 1.40 & 27.40 & 190.78 & 7.53 & 77.67 & 14.33 \\
\hline JAN & 108.66 & 10.92 & 1.44 & 35.33 & 196.27 & 6.88 & 78.25 & 17.46 \\
\hline CD at 5\% & $\mathbf{6 . 4 9}$ & $\mathbf{4 . 5 3}$ & $\mathbf{N S}$ & $\mathbf{N S}$ & $\mathbf{1 4 . 3 2}$ & $\mathbf{1 . 2 7}$ & $\mathbf{1 2 . 3 4}$ & $\mathbf{1 0 . 7 3}$ \\
\hline
\end{tabular}

Table.4 Morpho-phenological characters as affected by different growing periods during 2016-17

\begin{tabular}{|l|c|c|c|c|c|}
\hline Treatments & $\begin{array}{l}\text { Fruit set } \\
(\%)\end{array}$ & $\begin{array}{c}\text { Seed } \\
\text { Number/Fruit }\end{array}$ & $\begin{array}{c}\text { Seed Weight } \\
/(\mathrm{g})\end{array}$ & $\begin{array}{c}\text { Pollination } \\
\text { Period }\end{array}$ & $\begin{array}{c}\text { Gestation } \\
\text { period(days) }\end{array}$ \\
\hline FEB & 45.80 & 78.34 & 0.93 & Mid March & 110.0 \\
\hline MARCH & 48.05 & 82.66 & 0.97 & Mid April & 120.0 \\
\hline APRIL & 47.77 & 82.99 & 0.98 & $1^{\text {st }}$ Week of May & 130.0 \\
\hline MAY & 52.62 & 88.52 & 1.00 & 1 stWeek of June & 132.0 \\
\hline JUNE & 66.21 & 118.76 & 1.05 & $1^{\text {st }}$ Week of July & 135.0 \\
\hline JULY & 67.93 & 123.35 & 1.04 & Mid August & 135.0 \\
\hline AUG & 82.87 & 152.64 & 1.04 & Mid September & 130.0 \\
\hline SEPT & 86.22 & 163.25 & 1.02 & Mid October & 130.0 \\
\hline OCT & 28.24 & 34.67 & 0.67 & $3^{\text {rd }}$ Week of & 152.0 \\
\hline NOV & 42.96 & 72.88 & 0.92 & $3^{\text {rd }}$ Week of & 148.0 \\
\hline DEC & 45.45 & 77.67 & 0.98 & $2^{\text {nd }}$ February & 137.0 \\
\hline JAN & 50.71 & 80.23 & 0.98 & $3^{\text {rd }}$ Week Feb & 125.0 \\
\hline CD at 5\% & NS & $\mathbf{1 2 . 3 4}$ & $\mathbf{N S}$ & ..... & $\mathbf{1 1 . 4 2}$ \\
\hline
\end{tabular}


Table.5 Disease incidence as affected by the climate change effects from 2009-2017

\begin{tabular}{|l|l|l|l|l|l|l|l|l|l|}
\hline $\begin{array}{l}\text { Name of } \\
\text { The Pests }\end{array}$ & 2009 & 2010 & 2011 & 2012 & 2013 & 2014 & 2015 & 2016 & 2017 \\
\hline $\begin{array}{l}\text { Makhana } \\
\text { Aphid }\end{array}$ & NA* & Mild & Mild & Mild & Mild & Mild & Mild & $\begin{array}{l}\text { Moderate } \\
\text { at nursery }\end{array}$ & $\begin{array}{l}\text { Moderate } \\
\text { at nursery }\end{array}$ \\
\hline $\begin{array}{l}\text { Makhana } \\
\text { Blight }\end{array}$ & NA* & $\ldots$. & Mild & Mild & Mild & Mild & Mild & Mild & Mild \\
\hline
\end{tabular}

NA* data are not available

Fig.1 Change in carbohydrate (\%) synthesis at different growing season 2016-17

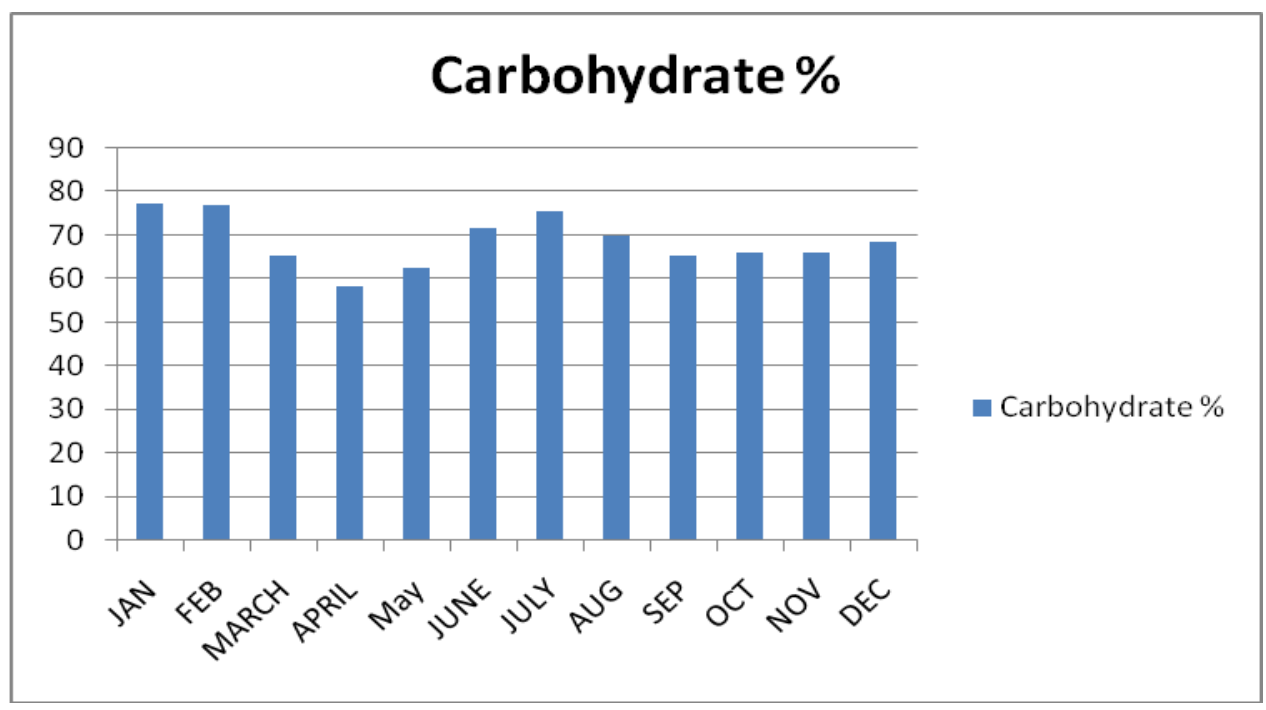

Fig.2 Change in protein (\%) at different growing season 2016-17

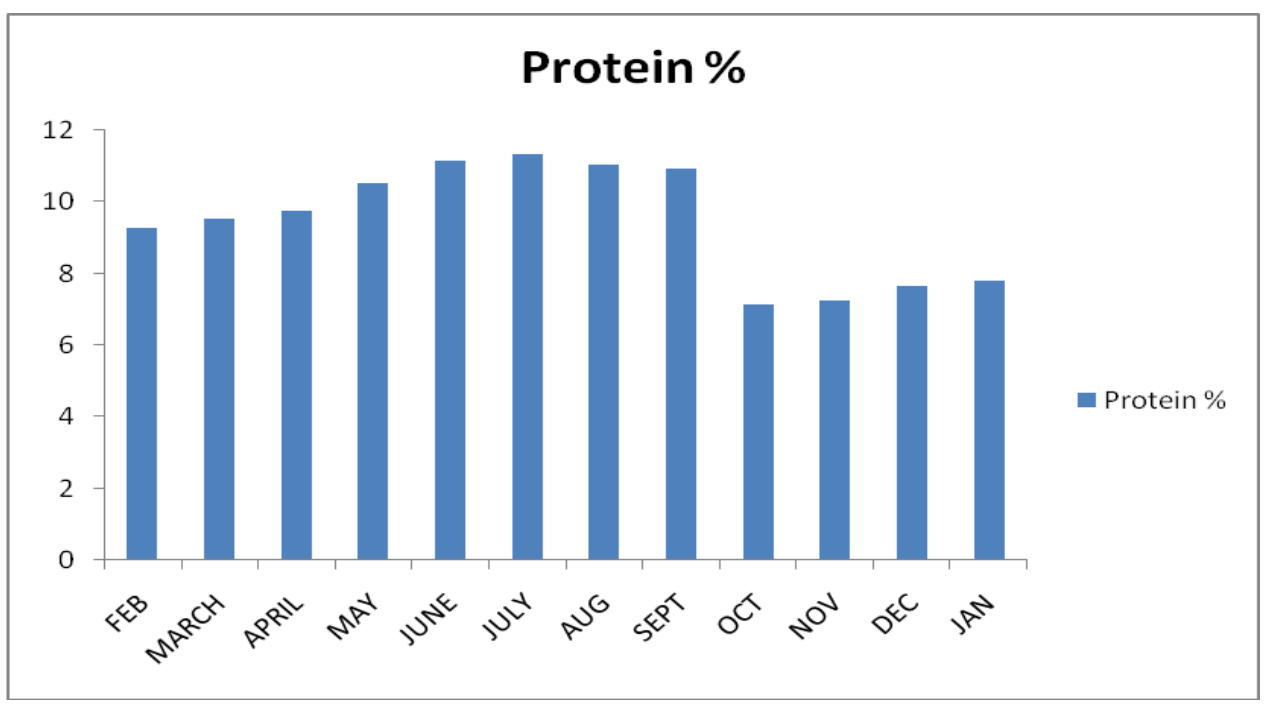


Fig.3 Biomass production of Makhana (Fresh and Dry) as affected by different growing seasons

\section{Biomass production as effertert py teldifferent growing seasons}

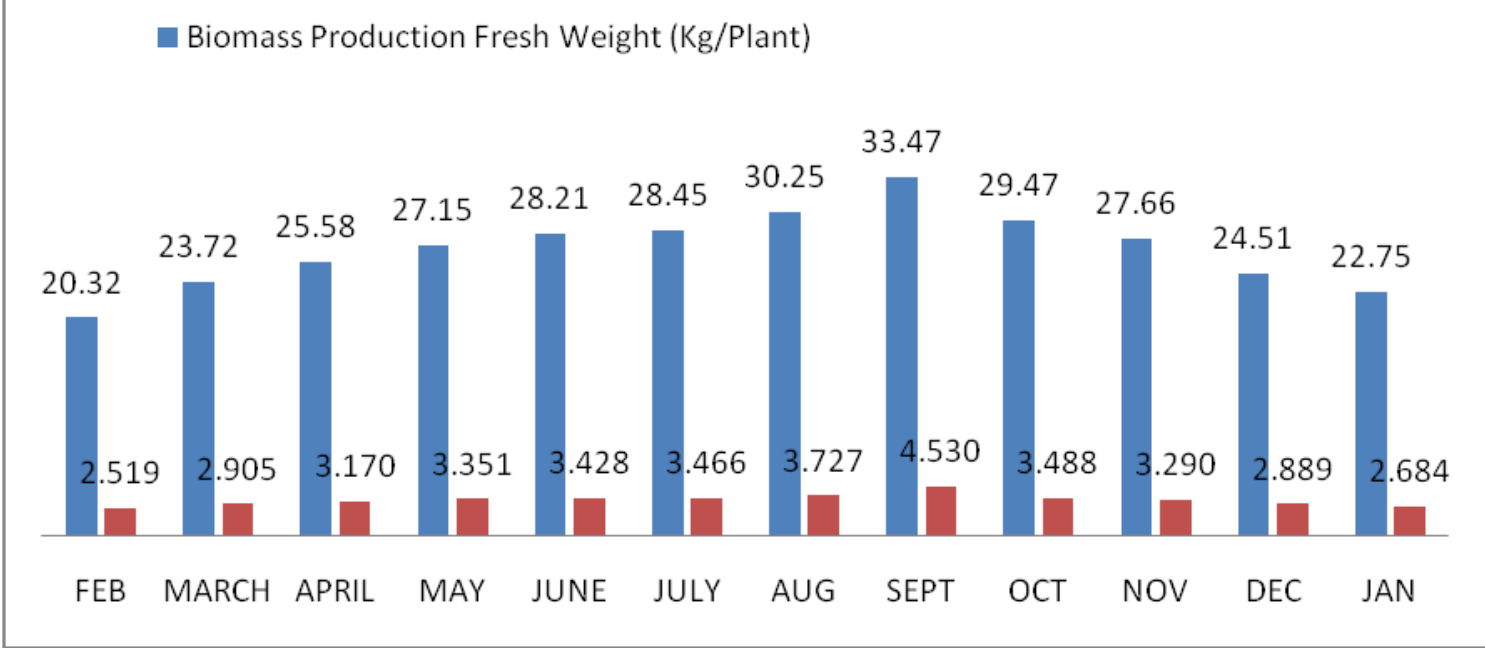

\section{Pest and diseases}

Makhana aphid (Rhopalosiphum nymphaeae) has become more prominent pest of Makhana in recent years (Table 5). Aphid infestation was found during nursery stage of Makhana plant. It is also mentioned as one of the major pest of makhana by Mishra et al., (1992) and Swaraswati et al., (1990). Makhana blight (Alternaria alternata) is not a serious disease till now. It's infestation is relatively mild in both the nursery and mature makhana plant. Makhana blight disease was also reported by Hyder and Nath (1987), Dwivedi et al., (1995).

\section{References}

Bensky, D., Gamble, A., and Kaptchuk, T. J. (1993). Chinese herbal medicine: Materia medica, rev. Ed. 1993 (Chin Herb Med.)

CSIR. (1952). The wealth of India: Raw Materials, CSIR, New Delhi III, 1952, 232.

Das, S., Der, P., Roychoudhury, U., Maulik, N. and Das, D. K. (2006). The effect of Euryale ferox (Makhana), an herb of aquatic origin, on myocardial ischemic reperfusion injury. Mol. Cell Biochem. 289 $(1-2): 55-63$.

Dwivedi, A.K., Shekhar, R. and Sharma, S.C. (1995). Ultrastructural studies of Euryale ferox leaf infected by Alternaria alternateIndian Phytopath. 48 (1): 61-65

Ferguson, lan B., Lurie, Susan, and Bowen, Judith H. (1994). Protein Synthesis and Breakdown during Heat Shock of Cultured Pear (Pyrus communis L.) Cells, Plant Physiol. 104: 1429-1437

Graham, D. and Patterson, B.D. (1982). Responses of plants to low, nonfreezing temperatures: proteins, metabolism, and acclimation. Annu Rev Plant Physiol 33: 347-372

Haidar, M.G. and Nath, R.P. (1987). Chemical control of Alternaria leaf blight of Makhana (Euryale ferox). Nat. Acad. Sci. Lett. 10: 301-302.

Hatfield, J.L., Boote, K.J., Kimball, B.A., Ziska, L.H., Izaurralde, R.C., Ort D., Thomson, A.M. and Wolfe, D.W. (2011). Climate impacts on agriculture: implications for crop production. Agron. J., 103: pp. 351370

Hesse, P.R. (1971). A Textbook of Soil Chemical Analysis. (Ed.) Hesse, P.R., John Murray, London, pp. 255-300. 
Intergovernmental Panel Climate Change (IPCC).)(2007). Climate Change 2007: Impacts, Adaptation and Vulnerability: Contribution of Working Group II to the Fourth Assessment Report of the Intergovernmental Panel on Climate Change. Cambridge University Press, Cambridge, U.K. and New York, NY.

Jackson, M.L. (1973). Soil Chemical Analysis. Prentice Hall of India Pvt. Ltd., New Delhi.

Jana,B.R. (2017). Impact of water depth on growth of gorgon nut and associated weed under wetland ecosystem of North Bihar province in India. Journal of Crop and Weed, 13(1): 77-82

Jha, V, Kargupta, A.N., Dutta, R.N., Jha, U.N., Mishra, R.K. and Saraswati, K.C. (1991b). Utilization and Conservation of Euryale ferox Salisbury in Mithila (North Bihar) India. Aquatic Botany. 39: 259-314.

Jha, V., Barat, G.K. and Jha, U.N. (1991a). A Nutritional evaluation of Euryale ferox Salisb (Makhana). Journal of Food Science and Technology. 8 (5):326-28.

Jha, Vaidyanath. (2002). Sustainable management of biotic resources in the wetlands of North Bihar, India. Lake 2002 CES, Bangalore. Folder-48

JIT Report. (2014). Mission for Integrated Development of Horticulture in Bihar, 31st May to 4th June, 2014. Ministry of Agriculture, Department of Agriculture \&Cooperation, Krishi Bhawan, New Delhi. P-7

Kak, A. M. (1985). Aquatic and wetland vegetation of the north western HimalayaXXI. Family Nymphaeaceae in the north western Himalaya J. Econ. Taxon. Bot. 7:591-598

Kumar, Lokendra, Gupta, V.K., Jha, B.K., Singh, I.S. Bhatt, B.P. and Singh, A.K. (2011). Status of makhana (Euryale ferox Salisb.) cultivation in India-Tech Bull. No. R32/PAT-21 ICAR-RCER Patna. P-31

Kumari, A., Singh. I.S., Kumar. Lokendra., Kumar, Amit., Kumar, Ramesh. and Gupta, V.K. (2014). Morphological characteristics of makhana germplasm of Manipur and Darbhanga conditions. Journal of AgriSearch. 1(3):157-170

Mandal, R.N., Saha, G.S. and Sarangi, N. (2010). Harvesting and processing of makhana (Euryale ferox Salisb.)-a unique assemblage of traditional knowledge. Indian Journal of Traditional Knowledge. 9 (4): 684-688.

Mishra, R.K., Jha, B.P.; Jha, V. Singh, S.K., and Mahto, A. (1992). Insect associations of Euryale ferox Salisb. in ponds of Darbhanga North Bihar. J. Freshwater Biol. 4(3): 199-208.

Okada Y. (1935). Study on Euryale ferox Salisb. VIII. Miscellany Sci. Rep. Tohoku. Imp. Univ. Ser IV. 2: 455-59.

Ranganna, S. (1997). Manual of analysis of fruits and vegetables product. Tata McGraw-Hill Publishing Co. Ltd. New Delhi. Pp: 29-31.

Saraswati, K.C., Mishra, R.K., Kumar, R., and Jha, V. (1990). Rhopalosiphum nymphaeae Linn. Infestation on the leaves of Euryale ferox in Darbhanga. J. Aphidol. 4 (1-2) : 89-92.

Shankar, Mamta., Neha, Chaudhary and Dheer, Singh. (2010). A Review on Gorgon Nut. International Journal of Pharmaceutical \& Biological Archives. 1(2): 101-107 Available Online at www.ijpba.info.

Singh, A.B. Arora, R.K. (1978). Wild edible plants of India. ICAR, New Delhi. 257

Thimmaiah, S.R. 1999. Standard methods of biochemical analysis. Kalyani Publishers. New Delhi, India.

\section{How to cite this article:}

Jana, B.R., Anuradha Srivastava and Md. Idris. 2018. Climate Change Effects and Quality Makhana (Euryale ferox Salisb.) Production under Wetland Ecosystem of North Bihar. Int.J.Curr.Microbiol.App.Sci. 7(12): 578-587. doi: https://doi.org/10.20546/ijcmas.2018.712.072 
Appendix -1

Weather Reports of Darbhanga
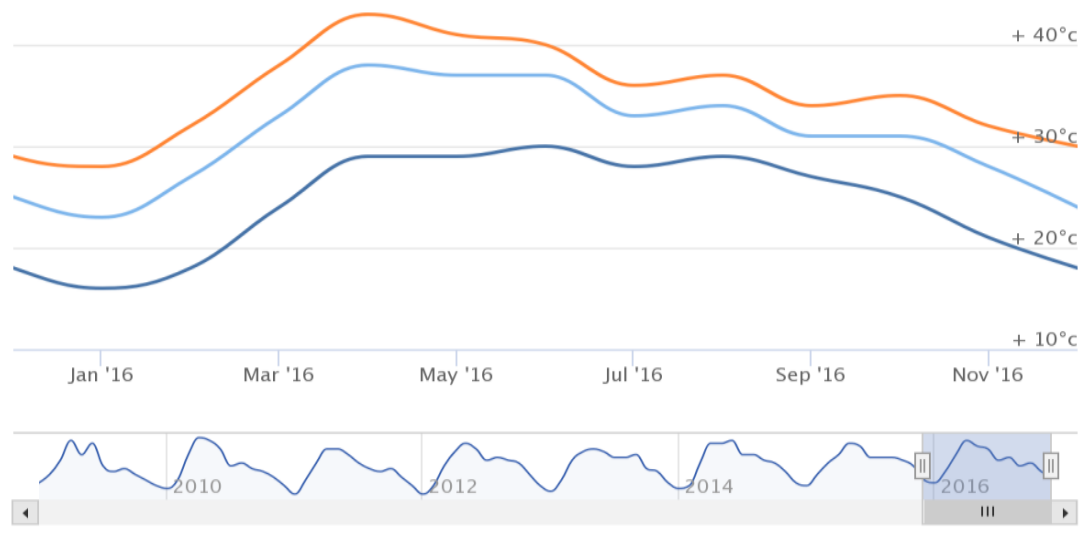

- Max Temp $\left({ }^{\circ} \mathrm{C}\right)-\operatorname{Min} \operatorname{Temp}\left({ }^{\circ} \mathrm{C}\right)-\operatorname{Avg} \operatorname{Temp}\left({ }^{\circ} \mathrm{C}\right)$

(A) Changes in Temperature
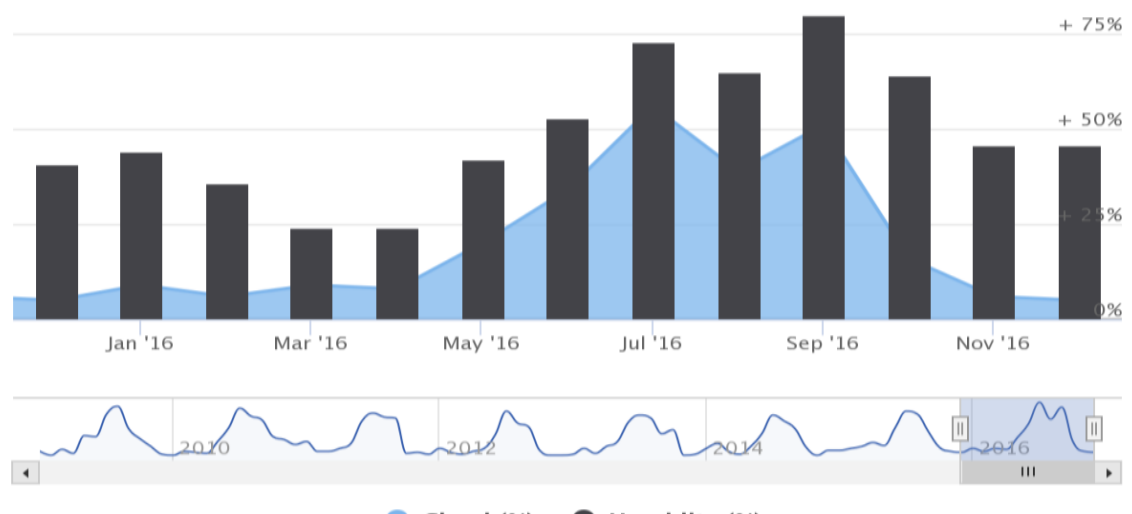

- Cloud (\%) - Humidity (\%)

(B) Changes in Humidity
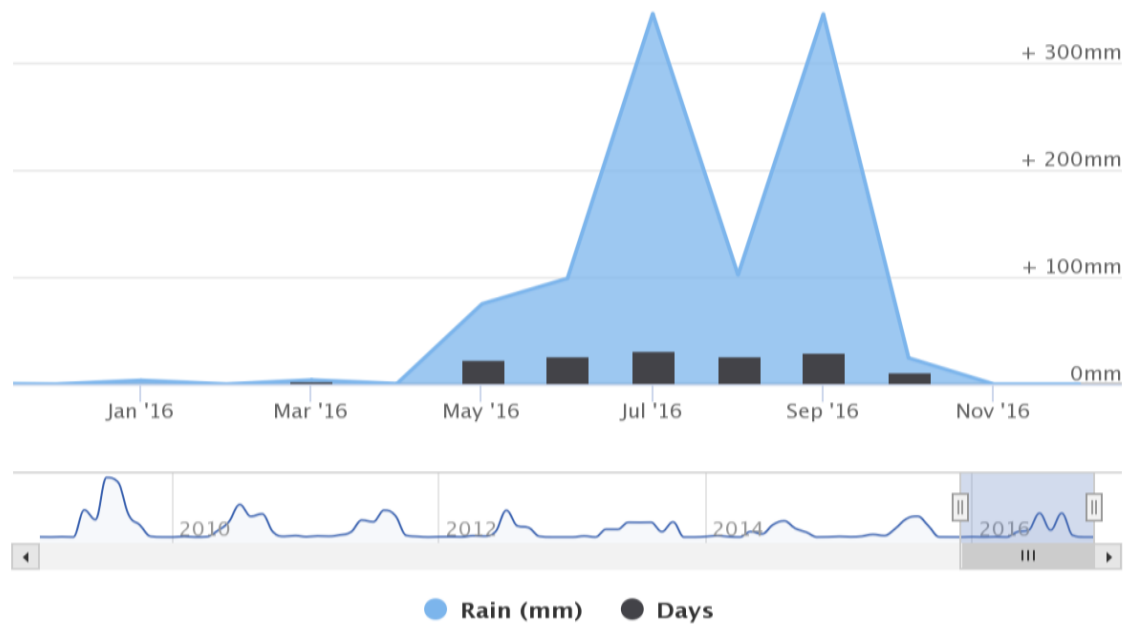

(C) Changes in Rainfall 
Table.1 Climate data of Darbhanga (2017) till crop harvest

\begin{tabular}{|c|c|c|}
\hline Months (2017) & Temperatures $\left({ }^{\circ} \mathrm{C}\right)$ & Humidity (\%) \\
\hline JAN & 17.0 & 78.0 \\
\hline FEB & 22.0 & 65.0 \\
\hline MARCH & 25.0 & 60.0 \\
\hline APRIL & 30.0 & 54.0 \\
\hline MAY & 31.0 & 61.0 \\
\hline JUNE & 32.0 & 70.0 \\
\hline
\end{tabular}

